\title{
TERMIN DO UZUPEŁNIENIA NALEŻNEJ OPŁATY PRZEZ PROFESJONALNEGO PEŁNOMOCNIKA W RAZIE WNIESIENIA ZAŻALENIA NA ZARZĄDZENIE O ZWROCIE POZWU
}

\section{UWAGI WSTĘPNE}

Celem opracowania jest odpowiedź na pytanie, czy przepis art. $130^{2} \S 2$ k.p.c. ma zastosowanie w przypadku oddalenia zażalenia ${ }^{1}$ na zarządzenie o zwrocie pozwu z powodu braku fiskalnego? Powstaje bowiem wątpliwość, czy dopuszczalne jest uzupełnienie braku fiskalnego, w przypadku wniesienia pisma przez profesjonalnego pełnomocnika, w terminie siedmiodniowym od doręczenia postanowienia o oddaleniu zażalenia na zarządzenie o zwrocie pozwu. W art. $130^{2}$ $\S 2$ k.p.c. ustawodawca dopuścił możliwość uzupełnienia braku, ale „W terminie tygodniowym od dnia doręczenia zarządzenia o zwrocie pisma". W przepisie początek biegu terminu do uzupełnienia określony został na dzień doręczenia zarządzenia o zwrocie pisma. Powstaje wątpliwość, czy pełnomocnik, który otrzymał zarządzenie powinien uzupełnić opłatę i wnieść zażalenie, czy też może wnieść zażalenie, a w razie oddalenia zażalenia, rozpocznie bieg termin siedmiodniowy do uzupełnienia braku².

1 Zgodnie z art. 394 § 1 pkt. 1 k.p.c. zażalenie do sądu drugiej instancji przysługuje na zarządzenia przewodniczącego, którego przedmiotem jest zwrot pozwu.

2 Postanowieniem z dnia 17 października 2012 r., III CZP 59/12, «Lex» nr 1243043, SN odmówił z przyczyn formalnych odpowiedzi na następujące zagadnienie prawne przedstawione przez SO w Poznaniu: „Czy uregulowanie zawarte w art. $130^{2} \S 2$ k.p.c. na- 
Do przedmiotowego problemu odniósł się SN w uzasadnieniu wyroku z dnia 13 października 2009 r., II PK 96/09, «Lex» nr 55940, stwierdzając, że początek biegu siedmiodniowego terminu do wniesienia należnej opłaty na podstawie art. $130^{2} \S 2$ k.p.c., można liczyć od doręczenia postanowienia Sądu oddalającego zażalenie na zarządzenie o zwrocie pozwu. Zdaniem SN: „Powyższe stanowisko uzasadnione jest tym, iż niedopuszczalne jest wyciąganie niekorzystnych dla strony konsekwencji procesowych w sytuacji, gdy stronie przysługiwały w świetle przepisów procedury wyżej wskazane alternatywne działania". Zwraca jednak uwagę lakoniczność uzasadnienia dla zajętego stanowiska, która uzasadniona jest tym, że powyższe rozważania w przedmiotowej sprawie miały charakter hipotetyczny, bowiem powód nie uiścił opłaty w terminie 7 dni od doręczenia postanowienia oddalającego zażalenie powoda na zarządzenie przewodniczącego o zwrocie pozwu.

W niniejszym artykule wskazano, że wykładnia systemowa oraz funkcjonalna mogą przemawiać za stanowiskiem, zgodnie z którym możliwe jest odejście od wykładni gramatycznej art. $130^{2} \S 2$ k.p.c., i uzupełnienie opłaty w terminie siedmiu dni od doręczenia postanowienia sądu oddalającego zażalenie na zarządzenie o zwrocie pozwu. Jednocześnie jednak wskazano argumenty przemawiające za stanowiskiem przeciwnym.

Za trafne należy uznać pierwsze stanowisko. Przeciwny pogląd zakłada, że wnoszący pozew, jeżeli chce wnieść zażalenie na zarządzenie o zwrocie pozwu, powinien dokonać dwóch czynności procesowych, tj.: 1) uzupełnić brak fiskalny, 2) wnieść zażalenie. Tyle tylko, że skutkiem uzupełnienia opłaty jest przyjęcie, że pismo wywołało skutek od daty pierwotnego wniesienia, a w konsekwencji zostało należycie opłacone. Jeżeli tak, to brak jest interesu prawnego do wniesienia zażalenia. Ponadto, przyjęcie powyższego poglądu zakłada, że należycie opłacone zostało pismo, w analizowanym przypadku pozew,

leży interpretować ściśle - zgodnie z jego literalnym brzmieniem - jedynie do przypadku biegu tygodniowego terminu do wniesienia opłaty sądowej od dnia doręczenia zarządzenia o zwrocie pozwu, czy możliwość uiszczenia tej opłaty zachodzi również po uprawomocnieniu się tego zarządzenia w razie oddalenia wywiedzionego na nie zażalenia?”. 
w sytuacji kiedy wniesiono zażalenie na zarządzenie o zwrocie pozwu z powodu nieuiszczenia właściwej opłaty.

Należy podkreślić, że wykładnia gramatyczna art. $130^{2} \S 2$ k.p.c. nie odpowiada na przedmiotowe wątpliwości. Przepis dotyczy sytuacji, kiedy to strona uzupełniła w terminie siedmiodniowym brak fiskalny. Nie ma natomiast przepisu, który odpowiadałby na pytanie, czy po oddaleniu zażalenia na zarządzenie o zwrocie pisma, dopuszczalne jest uzupełnienie braku fiskalnego. Na to pytanie nie odpowiada wprost art. $130^{2} \S 2$ k.p.c. Przepis dotyczy bowiem sytuacji, kiedy to strona uzupełniła brak fiskalny. W istocie chodzi o pytanie, czy może on zostać zastosowany w sytuacji oddalenia zażalenia na zarządzenie o zwrocie pozwu.

Ustawodawca nie uregulował ,wprost” problemu analizowanego $\mathrm{w}$ niniejszym artykule $\mathrm{z}$ uwagi na technikę legislacyjną, albowiem wnoszenie zażaleń na zarządzenia przewodniczącego zostało uregulowane w części k.p.c. poświęconej środkom zaskarżenia. Wniesienie środka zaskarżenia przez stronę nie może stanowić okoliczności, która stawia ją w gorszej sytuacji procesowej niż stronę, która nie wniosła środka zaskarżenia. Strona ma prawo tak do przeprowadzenia postępowania naprawczego, o którym mowa w art. $130^{2} \S 2$ k.p.c., jak i do wniesienia zażalenia. Wykładnia przepisów k.p.c. powinna dawać możliwość skorzystania $\mathrm{z}$ tych uprawnień. Zróżnicowanie sytuacji, kiedy to pismo wnosi sama strona (art. 130 k.p.c.) ${ }^{3}$ jak i strona reprezentowana przez profesjonalnego pełnomocnika (art. $130^{2}$ k.p.c. $)^{4}$

3 Jeżeli pismo procesowe nie może otrzymać prawidłowego biegu wskutek niezachowania warunków formalnych lub jeżeli od pisma nie uiszczono należnej opłaty, przewodniczący wzywa stronę, pod rygorem zwrócenia pisma, do poprawienia, uzupełnienia lub opłacenia go w terminie tygodniowym (art. $130 \S 1$ zd. 1 k.p.c.). Szczegółowe regulacje dotyczą wniesienia pozwu w elektronicznym postępowaniu upominawczym (art. 130 § 6 k.p.c.). Bezskuteczny upływ terminu skutkuje wydaniem przez przewodniczącego zarządzenia o zwrocie pozwu, a pismo zwrócone nie wywołuje żadnych skutków, jakie ustawa wiąże z wniesieniem pisma procesowego do sądu (art. 130 § 2 k.p.c.). Zarządzenie o zwrocie pozwu zaskarżalne jest zażaleniem (art. $394 \S 1$ pkt. 1 k.p.c.).

4 Ustawodawca oddzielnie uregulował wniesienie opłaty przez profesjonalnego pełnomocnika. Zgodnie z art. $130^{2} \S 1$ k.p.c.,,Pismo wniesione przez adwokata, radcę 
ma na celu usprawnienie postępowania w drugim przypadku, ale w żadnym razie nie może prowadzić do naruszenia praw procesowych strony, zagwarantowanych przez Konstytucję, które nie zależą przecież od tego, czy strona jest reprezentowana przez profesjonalnego pełnomocnika, czy też nie.

prawnego lub rzecznika patentowego, które nie zostało należycie opłacone, przewodniczący zwraca bez wezwania o uiszczenie opłaty, jeżeli pismo podlega opłacie w wysokości stałej lub stosunkowej obliczonej od wskazanej przez stronę wartości przedmiotu sporu”. Na podstawie $\S 2$,W terminie tygodniowym od dnia doręczenia zarządzenia o zwrocie pisma z przyczyn określonych w $\S 1$ strona może uiścić brakującą opłatę. Jeżeli opłata została wniesiona we właściwej wysokości, pismo wywołuje skutek od daty pierwotnego wniesienia. Skutek taki nie następuje w razie kolejnego zwrotu pisma z tej samej przyczyny”. A zatem w art. $130^{2}$ k.p.c. ustawodawca ujął wyjątki od zasad dotyczących skutków uchybień fiskalnych pism procesowych zawartych w art. 130 k.p.c. (Zob. szerzej m.in. T. ŻYZNOwsKI, [w:] Kodeks postępowania cywilnego. Komentarz, I, pod red. H. DoleckIEGo i T. WiśnIEWSKIEGO, Warszawa 2011, s. 470). W uzasadnieniu postanowienia z dnia 18 stycznia 2010 r., II UZ 48/09, «Lex» nr 583830, SN podkreślił, że: „Zasady postępowania po stwierdzeniu, że pismo procesowe nie zostało opłacone, są zróżnicowane w zależności od sytuacji procesowej, w jakiej pozostaje strona. Jeżeli bowiem pismo wnosi strona niezastępowana przez profesjonalnego pełnomocnika, to zgodnie z art. 130 § 1 k.p.c. przewodniczący wzywa ją do opłacenia tego pisma w terminie tygodniowym (niezależnie od rodzaju opłaty, którą należy uiścić). Nie ma natomiast obowiązku wzywania do opłacenia pisma procesowego podlegającego opłacie w wysokości stałej lub stosunkowej obliczonej od wskazanej przez stronę wartości przedmiotu sporu, jeżeli wnoszone jest ono przez profesjonalnego pełnomocnika (adwokata, radcę prawnego, rzecznika patentowego), co wynika z art. $130^{2} \S 1$ k.p.c. Profesjonalny pełnomocnik ma zatem obowiązek samoobliczenia i samoopłacenia opłat sądowych (w wysokości stałej i stosunkowej) od wnoszonych przez siebie pism procesowych. Przez nieopłacenie pisma procesowego rozumieć należy więc nieuiszczenie należnej opłaty pomimo upływu terminu udzielonego stronie działającej bez pełnomocnika na dokonanie tej czynności, a przy pismach procesowych wnoszonych przez profesjonalnych pełnomocników, nieuiszczenie takiej opłaty przy wnoszeniu pisma podlegającego opłacie w wysokości stałej lub stosunkowej. Skutkiem nieopłacenia pisma procesowego jest jego zwrot (art. 130 $\S 2$ k.p.c., art. $130^{2} \S 1$ k.p.c.), z wyjątkiem jednak przypadków, gdy według przepisów szczególnych skutkiem nieopłacenia danego rodzaju pisma procesowego jest jego odrzucenie". 
2. ARgUMENTY PRZEMAWIAJĄCE ZA KONCEPCJĄ, ZGODNIE Z KTÓRĄ ART. $130^{2} \S 2$ K.P.C. MA ZASTOSOWANIE W RAZIE ODDALENIA ZAŻALENIA NA ZARZĄDZENIE O ZWROCIE POZWU Z POWODU BRAKU FISKALNEGO

Po pierwsze, za niewystarczającą należy uznać wykładnię gramatyczną art. $130^{2} \S 2$ k.p.c. Oparcie się wyłącznie o powyższą wykładnię prowadzi do wniosku, że osoba, która wniosła zażalenie powinna jednocześnie uzupełnić brak fiskalny, czyli dokonać dwóch czynności procesowych. Dokonanie dwóch czynności procesowych jest w powyższym przypadku niedopuszczalne, albowiem uzupełnienie braku fiskalnego sprawia, że pismo zostało należycie opłacone, a tym samym brak jest interesu prawnego do wniesienia zażalenia od zarządzenia, które co do zasady staje się prawomocne $\mathrm{z}$ chwilą opłacenia (art. 360 k.p.c. w zW. z art. 362 k.p.c.). Uzupełnienie opłaty sprawia, że zarządzenie o zwrocie stało się bezskuteczne, a skoro tak to brak jest interesu prawnego do wniesienia zażalenia. Z drugiej strony przepisy k.p.c. przyznają wprost zażalenie na zarządzenie o zwrocie pozwu. Wniesienie zażalenia nie może pozbawiać strony możliwości uzupełnienia braku fiskalnego w razie oddalenia zażalenia. Skoro strona nie może dokonać jednocześnie dwóch czynności procesowych, tzn. uzupełnienia braku i wniesienia zażalenia na zarządzenie, to należy przyjąć, że wniesienie zażalenie nie może pozbawiać strony możliwości uzupełnienia braku fiskalnego.

Przesłanką pozytywną wniesienia zażalenia nie jest wykonanie zarządzenia sądu. Przesłanką wniesienia zażalenia nie jest właściwe opłacenie pisma.

Dobrowolne uzupełnienie opłaty oznacza, że strona zgadza się z zarządzeniem o zwrocie, a skoro tak to nie ma interesu prawnego do wniesienia zażalenia.

Wątpliwości zatem budzi konstrukcja, zgodnie z którą strona, która chce wnieść zażalenie na zarządzenie o zwrocie pisma z powodu braku fiskalnego, powinna wcześniej taki brak uzupełnić.

Po drugie, art. $130^{2} \S 2$ k.p.c. ma odpowiednie zastosowanie do sytuacji, w której sąd oddalił zażalenie na zarządzenie o zwrocie pisma z powodów braków fiskalnych, albowiem przepis ten stanowi wyjątek 
od zasady skuteczności postanowień z chwilą ich ogłoszenia, która wyrażona jest w art. 360 k.p.c., mającym odpowiednie zastosowanie do zarządzeń przewodniczącego na podstawie art. 362 k.p.c. Zarządzenie staje się skuteczne jeżeli brak fiskalny nie zostanie usunięty w terminie siedmiu dni od oddalenia zażalenia na zarządzenie o zwrocie pisma. Skorzystanie z zażalenia nie może prowadzić do wyłączenia stosowania art. $130^{2} \S 2$ k.p.c. Strona procesowa reprezentowana przez profesjonalnego pełnomocnika musi mieć możliwość uzupełnienia braku fiskalnego, niezależnie od tego, czy zostało wniesione zażalenie, czy też nie.

Niedopuszczalny jest zatem swoisty „dualizm”, kiedy to w razie wniesienia zażalenia zarządzenie staje się skuteczne, a tym samym nie obowiązuje art. $130^{2} \S 2$ k.p.c., a w przypadku niewniesienia zażalenia jest bezskuteczne w razie uzupełnienia braku fiskalnego. Art. $130^{2} \S 2$ k.p.c. dotyczy zarządzenia o zwrocie pisma wniesionego przez profesjonalnego pełnomocnika, niezależnie od tego, w jaki sposób postąpi powód, tzn. czy uzupełni brak fiskalny, czy też wniesie zażalenie. Zażalenie jest wnoszone od tego samego zarządzenia o zwrocie pozwu, którego brak może zostać uzupełniony.

Za przyjętym rozwiązaniem przemawia zatem jedna z reguł wykładni, która brzmi „lege non distinguente”, a zatem skoro ustawodawca przewiduje możliwość uzupełnienia braku przez samą stronę w razie niewniesienia zażalenia, to także zapewnia możliwość uzupełnienia braku w razie wniesienia zażalenia. Przepis art. $130^{2} \S 2$ k.p.c. wprowadza wyjątek zarówno od zasady, zgodnie z którą postanowienie sądu pierwszej instancji jest skuteczne (art. 360 k.p.c. w zW. z art. 362 k.p.c.), jak i od zasady, zgodnie z którą wykonalne, czyli skuteczne są orzeczenia sądu drugiej instancji, w niniejszym przypadku chodzi o postanowienie oddalające zażalenie.

Należy podkreślić, że $\mathrm{w}$ analizowanym przypadku nie może mieć zastosowania art. 396 k.p.c., dotyczący wstrzymania wykonania zaskarżonego postanowienia przez sąd pierwszej instancji do czasu rozstrzygnięcia zażalenia, albowiem termin określony w art. $130^{2} \S 2$ k.p.c., jako termin ustawowy nie może być zmieniany przez strony, ani przez sąd.

Po trzecie, A. Górski i L. Walentynowicz komentując art. $130^{2} \S$ 2 k.p.c. podkreślili, że ustawodawca: „umożliwił wnoszącemu pismo 
dokonanie jego prawidłowego opłacenia w terminie tygodniowym od doręczenia zarządzenia o zwrocie pisma. Praktycznie ustanowił w ten sposób dodatkowy tygodniowy termin do uiszczenia opłaty"5. Brak jest podstaw do przyjęcia poglądu, iż strona wnosząca zażalenie nie może z powyższego terminu skorzystać.

W pełni zgodne są z powyższym twierdzeniem rozważania zawarte w uzasadnieniu uchwały SN z dnia 28 listopada 2006 r., III CZP 98/06, «Lex» nr 198917, w której przyjęto, że: „W razie oddalenia zawartego w apelacji wniosku o zwolnienie od kosztów sądowych przewodniczący wzywa do uiszczenia opłaty należnej od apelacji także wtedy, gdy wniósł ją adwokat". Uzasadniając zajęte stanowisko SN podkreślił, że: „problem dotyczy wymagania prawnego, którego niezachowanie jest zagrożone surową sankcją odrzucenia środka odwoławczego lub środka zaskarżenia, a więc pociąga za sobą dla strony poważne negatywne konsekwencje procesowe. Przesłanki zastosowania i rodzaj rygoru procesowego muszą wynikać z przepisu, nie można ich domniemywać ani „wprowadzać” w wyniku zabiegów interpretacyjnych. Niedopuszczalne jest wyciąganie niekorzystnych dla strony konsekwencji procesowych wtedy, gdy rygor nie został w sposób niewątpliwy określony w przepisie". Ostatnie zdanie uzasadnienia zasługuje na szczególną uwagę.

Po czwarte, nie budzi wątpliwości, że art. $130^{2} \S 2$ k.p.c. stanowi wyjątek od zasady skuteczności z chwilą ogłoszenia postanowień. Zarządzenie o zwrocie pisma stanie się skuteczne z chwilą upływu do uzupełnienia braku fiskalnego. Wątpliwości budzi konstrukcja, zgodnie z którą zarządzenie stanie się skuteczne w trakcie rozpoznawania zażalenia przez sąd drugiej instancji. Jeżeli zarządzenie nie jest skuteczne z chwilą ogłoszenia to należy przyjąć, iż celem ustawodawcy było dopuszczenie możliwości kontroli sądowej zgodności z prawem wydanego zarządzenia. Wniesienie zażalenia sprawia, że sprawę rozpoznaje sąd drugiej instancji. Niedopuszczalna jest konstrukcja, iż sąd ten nie ma wpływu na skuteczność lub też brak skuteczności zarządzenia.

5 A. Górski, L. Walentynowicz, Koszty sądowe w sprawach cywilnych, Warszawa 2008, s. 187. 
Art. $130^{2} \S 2$ k.p.c. stanowi lex specialis wobec art. $360 \mathrm{w} \mathrm{zw} . \mathrm{z}$ art. 362 k.p.c. i określa skuteczność zarządzenia tak w przypadku wniesienia, jak i niewniesienia zażalenia.

Należy podkreślić, że dany przepis nie stanowi wyjątku, który wymagałby wykładni ścisłej, zgodnie z regułą exceptiones non sunt extendendae, ale stanowi lex specialis wobec regulacji zawartej $\mathrm{w}$ art. 360 k.p.c. Brak jest uzasadnienia, ażeby wprowadzone przez przepis postępowanie naprawcze ograniczyć wyłącznie do sytuacji, kiedy to nie zostało wniesione zażalenie. Uzależnienie postępowania naprawczego od wniesienia zażalenia, stawia w gorszej sytuacji procesowej stronę korzystającą ze środka zaskarżania zarządzenia.

Po piąte, trudno jest przyjąć, iż może zostać nadany bieg pismu, które sąd uznaje za należycie opłacone, przed rozpoznaniem zażalenia. Powód uzupełnił pozew a jednocześnie wniósł zażalenie. Jeżeli sąd uwzględni zażalenie, a tym samym uchyli zarządzenie o zwrocie pozwu z powodu braku fiskalnego, ma miejsce sytuacja, kiedy to postępowanie zostało wszczęte i prowadzone na podstawie nienależycie opłaconego pisma. Ma zatem miejsce uchybienie procesowe. Rolą sądu jest kontrola pisma pod względem wymagań formalnych jak fiskalnych. Przed rozpoznaniem zażalenia przez sąd odwoławczy na zarządzenie o zwrocie pozwu z powodu braków fiskalnych, sąd nie ma pewności co do tego, czy pismo zostało należycie opłacone. Wprawdzie co do zasady wniesienie zażalenia nie wstrzymuje wykonania postanowienia, ale art. $130^{2} \S 2$ k.p.c. wprowadza wyjątek od tej zasady. Ponadto, nie należy zapominać, że pozew jest pierwszym pismem procesowym, wszczynającym postępowanie, stąd też szczególne znaczenie wskazania chwili skutecznego wniesienia pozwu.

Po szóste, za przyjętym rozwiązaniem przemawia konieczność ochrony dwóch podstawowych zasad postępowania, które wyrażone są w Konstytucji RP, a mianowicie zasady prawa do sądu oraz instancyjności postępowania ${ }^{6}$.

6 W postanowieniu z 23 stycznia 2001 r. (IV CKN 1621/00, «Lex Polonica» nr 389917) Sąd Najwyższy podkreślił, iż „Hierarchiczne usytuowanie Konstytucji i obowiązek bezpośredniego jej stosowania (art. 8 Konstytucji) nakazuje sądom stosowanie 
Prawo do sądu zgodnie z art. 45 ust. 1 Konstytucji polega na prawie do sprawiedliwego i jawnego rozpatrzenia sprawy bez nieuzasadnionej zwłoki przez właściwy, niezależny, bezstronny i niezawisły sąd. Prawo do sądu, jak podkreśla doktryna oraz orzecznictwo, obejmuje w szczególności: 1) prawo dostępu do sądu, tj. prawo do żądania wszczęcia postępowania przed sądem, 2) prawo do odpowiedniego ukształtowania procedury sądowej, która powinna odpowiadać zasadom sprawiedliwości i jawności, 3) prawo do wyroku sądowego, tj. prawo do rozstrzygnięcia sprawy przez sąd ${ }^{7}$. Zgodnie $\mathrm{z}$ art. 176. ust. 1 Konstytucji postępowanie sądowe jest co najmniej dwuinstancyjne.

SN podkreśla, iż wykładnia przepisów regulujących opłaty wnoszone przez profesjonalnych pełnomocników powinna być zgodna z zasadami procesowymi, w tym w szczególności, gwarantowanymi przez Konstytucję, oraz nie może uszczuplać praw strony reprezentowanej przez takich pełnomocników ${ }^{8}$.

ustawodawstwa zwykłego, w sposób umożliwiający stronom procesów sądowych realizację postanowień konstytucyjnych".

7 Por. Z. Czeszejko-Sochacki, Konstytucyjna zasada prawa do sadu, «PiP» 47.10/1992, s. 14 i n.; P. Pogonowski, Realizacja prawa do sadu w postępowaniu cywilnym, Warszawa 2005. Co do orzecznictwa zob. m.in.: wyrok z 9 czerwca 1998 r., sygn. K. 28/97, «OTK ZU» 4/1998, poz. 50; wyrok z dnia 10 maja 2000 r., sygn. K. 21/99, «OTK ZU» 4/2000, poz. 109; wyrok TK z 2 kwietnia 2001 r., sygn. SK 10/00, «OTK ZU» 3/2001, poz. 52; wyrok z 12 marca 2002 r., sygn. P 9/01, «OTK ZU» 2A/2002, poz. 14; orzeczenie z 25 lutego 2002 r., sygn. SK 29/01, «OTK» 1/2002, poz. 5; wyrok z 20 września 2006 r., sygn. SK 63/05, «OTK ZU» 8A/2006, poz. 108.

8 W uzasadnieniu uchwały SN z dnia 28 listopada 2006 r., III CZP 98/06, «Lex» nr 198917, SN uzasadniając pogląd, zgodnie z którym „W razie oddalenia zawartego w apelacji wniosku o zwolnienie od kosztów sądowych przewodniczący wzywa do uiszczenia opłaty należnej od apelacji także wtedy, gdy wniósł ją adwokat”, odwołał się do konieczności uwzględnienia zasad procesowych zawartych w Konstytucji RP. Zdaniem SN: „Żaden przepis ustawy o kosztach sądowych ani kodeksu postępowania cywilnego nie przewiduje obowiązku wzywania adwokatów do uiszczania opłat sądowych bez względu na ich rodzaj. Niespójność przepisów ustawy ujawnia się nie tylko w tym przypadku; należy więc tym bardziej wykładać ją i stosować tak, aby nie popadać w sprzeczność z zasadami procesowymi i nie uszczuplać - ponad to, co z samej ustawy wyraźnie wynika - praw stron procesu cywilnego". Jak dalej podkreślił SN: „To samo można powiedzieć o argumencie ogólnej natury, odwołującym się do 
Po siódme, wykładnia systemowa wymaga porównania postępowania naprawczego $\mathrm{w}$ razie braków fiskalnych pisma wniesionego przez samą stroną lub też przez profesjonalnego pełnomocnika. Zgodnie $\mathrm{z}$ art. $130 \S 1$ k.p.c. jeżeli pismo procesowe nie może otrzymać prawidłowego biegu wskutek niezachowania warunków formalnych lub jeżeli od pisma nie uiszczono należnej opłaty, przewodniczący wzywa stronę, pod rygorem zwrócenia pisma, do poprawienia, uzupełnienia lub opłacenia go w terminie tygodniowym. Mylne oznaczenie pisma procesowego lub inne oczywiste niedokładności nie stanowią przeszkody do nadania pismu biegu i rozpoznania go w trybie właściwym. Na podstawie $\S 2$,po bezskutecznym upływie terminu przewodniczący zwraca pismo stronie. Pismo zwrócone nie wywołuje żadnych skutków, jakie ustawa wiąże z wniesieniem pisma procesowego do sądu". A zatem najpierw jest wezwanie do usunięcia braków, a następnie zwrot pisma. Zażalenie jest wnoszone od zarządzenia o zwrocie, które jest skuteczne. W przypadku wniesienia pisma przez samą stronę zwrot następuje po wezwaniu do usunięcia braków. Strona ma alternatywę uzupełnić braki lub też wnieść zażalenie. Wykładnia systemowa wskazuje, że strona, niezależnie, czy jest reprezentowana przez profesjonalnego pełnomocnika, czy też nie, ma zagwarantowaną możliwość usunięcia braków jak i wniesienia zażalenia na zarządzenie o zwrocie. Niedopuszczalna jest sytuacja, w której strona musi dokonywać wyboru, albo usunąć braki albo wnieść zażalenie. Uznanie, że w razie wniesienia zażalenia strona nie może już uzupełnić braków fiskalnych nie ma podstawy normatywnej. Skorzystanie przez stronę z możliwości wniesienia zażalenia nie może jej pozbawiać możliwości uzupełniania braków fiskalnych.

„celowościowej wykładni nowej regulacji” i „intencji ustawodawcy”, zmierzającego do przyspieszenia postępowania. Taki postulat nie może być przez sądy realizowany kosztem praw procesowych stron, bez jednoznacznego oparcia w ustawie".

W uzasadnieniu postanowienia z dnia 28 października 2010 r., II UZ 26/10, «Lex» nr 707892, SN podkreślił, że: „szczególne wymagania oraz ograniczenia uprawnień procesowych powinny wyraźnie wynikać z przepisów ustawy oraz iż nie należy w drodze analogii stosować przepisów przewidujących takie ograniczenia, choćby w podobnych sytuacjach". 
Zróżnicowanie sytuacji, kiedy to pismo wnosi sama strona (art. 130 k.p.c.) jak i strona reprezentowana przez profesjonalnego pełnomocnika (art. $130^{2}$ k.p.c.) ma na celu usprawnienie postępowania $\mathrm{w}$ drugim przypadku, ale w żadnym razie nie może prowadzić do naruszenia praw konstytucyjnych strony, które nie zależą przecież od tego, czy strona jest reprezentowana przez profesjonalnego pełnomocnika, czy też nie. Przeciwny pogląd należałoby uznać za naruszający zasadę równości wobec prawa, która jest zagwarantowana przez Konstytucję (art. 32 ust. 1).

Nie można zatem przyjąć, że strona reprezentowana np. przez adwokata, nie może przeprowadzić postępowania naprawczego $\mathrm{z}$ art. $130^{2} \S 2$ k.p.c., które byłoby dopuszczalne jedynie wówczas, jeżeli nie zostanie wniesione zażalenie.

Postępowanie w sytuacji, kiedy to strona jest reprezentowana przez profesjonalnego pełnomocnika co do zasady powinno toczyć się szybciej niż kiedy strona występuje sama. Zasady procesowe, zagwarantowane tak przez Konstytucje, jak i akty prawa międzynarodowego, np. Europejską Konwencję o Ochronie Praw Człowieka i Podstawowych Wolności (art. 6) ${ }^{9}$, nie zależą od tego, czy strona w procesie występuje sama, czy też jest reprezentowana przez profesjonalnego pełnomocnika.

$\mathrm{W}$ kilku orzeczeniach $\mathrm{TK}^{10}$, podkreślono, że stosowanie surowszego rygoru w odniesieniu do pism procesowych, obarczonych brakami formalnymi, wnoszonych przez pełnomocników procesowych będących profesjonalistami, jest dopuszczalne. Zdaniem TK z samej bowiem istoty zastępstwa procesowego wypełnianego przez profesjonalnego pełnomocnika wynika uprawnione założenie, że pełnomocnik ten bę-

9 Konwencja weszła w życie wobec Rzeczypospolitej Polskiej dnia 19 stycznia 1993 r. (zob. Oświadczenie rządowe z dnia 7 kwietnia 1993 r. w sprawie ratyfikacji przez Rzeczpospolitą Polską Konwencji o ochronie praw człowieka i podstawowych wolności, sporządzonej w Rzymie dnia 4 listopada 1950 r., zmienionej następnie Protokołami nr 3, 5 i 8 oraz uzupełnionej Protokołem nr 2 (Dz.U. z 1993 r. Nr 61, poz. 285).

10 Por. np. wyrok z 12 września 2006 r., SK 21/05, «OTKZU» 8A/2006, poz. 103; wyrok z 17 listopada 2008 r., SK 33/07, «OTK-A» 9/2008, poz. 154: wyrok z 28 maja 2009 r., P 87/08, «OTK-A» 5/2009, poz. 72: wyrok z 14 września 2009 r., SK 47/07, «OTK-A» 8/2009, poz. 122. 
dzie działał fachowo, zgodnie ze swoją najlepszą wiedzą oraz należytą starannością. Powyższe stanowisko podziela również SN, podkreślają, iż wymagania formalne dotyczące pism procesowych stanowią elementarne zadanie warsztatowe ${ }^{11}$.

Analizowany w niniejszym artykule problem nie dotyczy jednak rygoryzmu wymagań warsztatowych profesjonalnych pełnomocników, ale wykładni przepisów k.p.c. dotyczących postępowania naprawczego, która budzi poważne wątpliwości. Naturalnie, wobec profesjonalnych pełnomocników należy stawiać wysokie wymagania, ale nie mogą być one wyinterpretowane z obowiązujących przepisów, zwłaszcza wówczas, jeżeli wykładnia taka może naruszać zagwarantowane przez Konstytucje RP podstawowe zasady procesowe.

Po ósme, ustawodawca uchylił $\uparrow^{12}$ przepis art. $130^{2} \S 3$ k.p.c., zgodnie z którym „Sąd odrzuca bez wezwania o uiszczenie opłaty pismo wniesione przez adwokata, radcę prawnego lub rzecznika patentowego środki odwoławcze lub środki zaskarżenia (apelację, zażalenie, skargę kasacyjną, skargę o stwierdzenie niezgodności z prawem prawomocnego orzeczenia, sprzeciw od wyroku zaocznego, zarzuty od nakazu zapłaty, skargę na orzeczenie referendarza sądowego) podlegające opłacie w wysokości stałej lub stosunkowej obliczonej od wskazanej przez stronę wartości przedmiotu zaskarżenia". Ustawodawca uchylił przepis pomimo orzeczeń TK, które uznały, że regulacja jest zgodna z Konstytucją RP ${ }^{13}$.

11 Por. uchwała SN z 22 lutego 2006 r., sygn. akt III CZP 6/06, «OSNC» 1/2007, poz. 5; postanowienie SN z dnia 18 stycznia 2010 r., II UZ 48/09, «Lex» nr 583830.

12 Przepis art. $130^{2} \S 3$ k.p.c., został ustawą z dnia 5 grudnia 2008 r. o zmianie ustawy - Kodeks postępowania cywilnego oraz niektórych innych ustaw (Dz. U. Nr 234, poz. 1571).

13 Zagadnienie zgodności z Konstytucją RP art. $130^{2} \S 3$ k.p.c. zostało rozstrzygnięte przez Trybunał Konstytucyjny w trzech wyrokach - z dnia 17 listopada 2008 r. sygn. SK 33/07, z dnia 28 maja 2009 r. sygn. P 87/09 oraz z dnia 14 września 2009 r. sygn. SK 47/07. Trybunał Konstytucyjny uznał że odrzucenie odpowiednio apelacji, zażalenia i zarzutów od nakazu zapłaty, które nie zostały opłacone, a wnoszone były przez profesjonalnego pełnomocnika, było dopuszczalne w świetle Konstytucji RP. Nie zachodziła zdaniem Trybunału Konstytucyjnego niezgodność art. $130^{2} \S 3$ k.p.c. z art. 45 ust. 1 oraz art. 78 Konstytucji. 
SN opowiadał się przeciwko rygorystycznej wykładni art. $130^{2} \S$ 3 k.p.c. uznając, że zaostrzenie wymogów formalnych i fiskalnych w przypadku wniesienia pisma przez wykwalifikowanego prawnika, nie może być wyinterpretowywane $\mathrm{z}$ obowiązujących przepisów ${ }^{14}$. Innymi słowy niedopuszczalna jest wykładnia rozszerzająca, w wyniku której doszłoby do dalszego zaostrzenia wymogów pism w razie wniesienia ich przez profesjonalnego pełnomocnika.

Po dziewiąte, zgodnie z art. $126^{2} \S 1$ k.p.c. sąd nie podejmie żadnej czynności na skutek pisma, od którego nie została uiszczona należna opłata. Należy podkreślić, że w przepisie chodzi nie o „opłatę”, ale o „należną” opłatę. W razie wniesienia zażalenia na zarządzenie o zwrocie pozwu, a jednocześnie uzupełnienia opłaty, nie wiadomo do czasu zakończenia postępowania zażaleniowego, czy opłata jest „należna”. Przepisy k.p.c. regulujące uchybienia fiskalne pism procesowych należy interpretować z uwzględnieniem brzmienia art. $126^{2}$ $\S 1$ k.p.c.

Ponadto, na podstawie art. $395 \S 2$ k.p.c. „Jeżeli zażalenie zarzuca nieważność postępowania lub jest oczywiście uzasadnione, sąd, który wydał zaskarżone postanowienie, może na posiedzeniu niejawnym, nie przesyłając akt sądowi drugiej instancji, uchylić zaskarżone postanowienie i w miarę potrzeby sprawę rozpoznać na nowo. Od ponownie

14 Przykładowo SN przyjął, iż „W razie oddalenia zawartego w apelacji wniosku o zwolnienie od kosztów sądowych przewodniczący wzywa do uiszczenia opłaty należnej od apelacji także wtedy, gdy wniósł ją adwokat" (zob. uchwała SN z dnia 28 listopada 2006 r., III CZP 98/06, «Lex» nr 198917). Zgodnie z uchwałą powiększonego składu Sądu Najwyższego z 15 czerwca 2010 r., II UZP 4/10, której nadano moc zasady prawnej: „Nieopłacona skarga kasacyjna złożona przez adwokata lub radcę prawnego po wejściu w życie ustawy z dnia 5 grudnia 2008 r. o zmianie ustawy - Kodeks postępowania cywilnego oraz niektórych innych ustaw (Dz. U. Nr 234, poz. 1571) podlega odrzuceniu w razie niewykonania zarządzenia wyzywającego do opłacenia skargi (art. $398^{6} \S 2$ k.p.c. w związku z art. $130 \S 1$ k.p.c.)”. Powyższe orzecznictwo straciło aktualność po zmianie treści art. 112 u.k.s.c. dokonanej ustawą z dnia 17 grudnia 2009 r. o zmianie ustawy - Kodeks postępowania cywilnego oraz niektórych innych ustaw (Dz. U. z 2010 r. Nr 7, poz. 45), obowiązującą od dnia 19 kwietnia 2010 r. (por. postanowienie SN z dnia 21 lipca 2011 r., V CZ 30/11, «Lex» nr 898279. Zob. także postanowienie SA we Wrocławiu z dnia 30 marca 2012 r., I ACz 582/12, «Lex» nr 1130923). 
wydanego postanowienia przysługują środki odwoławcze na zasadach ogólnych". Nie budzi wątpliwości, że zmiana zarządzenia przewodniczącego może zostać dokonana po upływie terminu siedmiodniowego wskazanego w art. $130^{2} \S 2$ k.p.c., albowiem ,adresatem” tego terminu jest strona. O tym zatem, czy opłata była należna jest wiadomo po zakończeniu postępowania zażaleniowego. Jeżeli pismo wnosi sama strona, też jest dopuszczalne zażalenie na zarządzenie o zwrocie pisma. W takim jednak przypadku zarządzenie o zwrocie pozwu jest skuteczne, a zatem postępowanie nie może się toczyć. W przypadku profesjonalnego pełnomocnika, który wniósłby jednocześnie opłatę oraz zażalenie, postępowanie by się toczyło, ale nie wiadomo, czy opłata była „należna”. Doszłoby zatem do naruszenia art. $126^{2} \S 1$ k.p.c. Innymi słowy odpowiedź na przedstawione wątpliwości powinna uniemożliwiać wystąpienie sytuacji, kiedy to postępowanie się toczy pomimo uiszczenia opłaty od pisma w niewłaściwej wysokości. Przepisy k.p.c. regulujące braki fiskalne pism wnoszonych przez samą stronę wykluczają taką możliwość (zob. art. 130 k.p.c.).

Po dziesiąte, wniesienie środka zaskarżenia orzeczenia, w analizowanym przypadku zażalenia, nie może wiązać się dla strony z negatywnymi konsekwencjami procesowymi (zakaz reformationis in peius). Zgodnie z art. 397 § 2 k.p.c. do postępowania toczącego się na skutek zażalenia stosuje się odpowiednio przepisy o postępowaniu apelacyjnym.

Zgodnie z art. 384 k.p.c. sąd nie może uchylić lub zmienić wyroku na niekorzyść strony wnoszącej apelację, chyba że strona przeciwna również wniosła apelację.

Odnosząc powyższy przepis do zażalenia na zarządzenie przewodniczącego, należy podkreślić, że jest on stosowany „odpowiednio” (art. $397 \S 2$ k.p.c.). W przepisie chodzi o to, ażeby sąd drugiej instancji nie pogorszył sytuacji procesowej wnoszącego apelację. Z takim pogorszeniem mamy do czynienia w przypadku oddalenia zażalenia, a tym samym upływu terminu do uzupełnienia przez stronę braku fiskalnego. Należy jednak podkreślić konieczność „ostrożnego” podejścia do zakazu reformationis in peius w powyższej sytuacji, tym bardziej, że niektórzy przedstawiciele doktryny wyłączają w ogóle możliwość jego 
stosowania $\mathrm{w}$ postępowaniu zażaleniowym ${ }^{15}$. Z drugiej jednak strony podkreśla się, że zakaz stwarza dla skarżącego ,gwarancję procesową, iż wywiedziona przez niego apelacja od błędnego wyroku nie pociągnie za sobą niekorzystnego z jego punktu widzenia rozstrzygnięcia sądu drugiej instancji" ". Nie budzi wątpliwości, że oddalenie zażalenia na zarządzenie o zwrocie pozwu prowadzi do negatywnych skutków dla skarżącego z uwagi na upływ terminu z art. $130^{2} \S 2$ k.p.c., jeżeli przyjmiemy wykładnię art. $130^{2} \S 2$ k.p.c., zgodnie z którą uzupełnić opłatę można jedynie $\mathrm{w}$ terminie siedmiodniowym od dnia doręczenia zarządzenia o zwrocie pozwu.

\section{ARguMENTY PRZEMAWIAJĄCE ZA STANOWISKIEM PRZECIWNYM}

Podstawowy argument dotyczy priorytetu wykładni gramatycznej art. $130^{2} \S 2$ k.p.c. Można jednak podać dwa kontrargumenty. Wykładnia gramatyczna nie wystarcza do udzielenia odpowiedzi na analizowany w opracowaniu problem. Przepis nie brzmi bowiem tak: „Strona wnosząca zażalenie obowiązana jest do uiszczenia opłaty". Skoro nie jest wystarczająca wykładnia gramatyczna należy odwołać się do wykładni funkcjonalnej oraz systemowej. Nie budzi wątpliwości, że dopuszczalne jest stosowanie wyjątków od zasady pierwszeństwa wykładni językowej. Reguła wykładni, zgodnie z którą wykładnia językowa ma charakter pierwszorzędny, nie ma charakteru absolutnego ${ }^{17}$. W artykule wykazano, że uwzględnienie wykładni funkcjonalnej i systemowej przemawia za aprobatą poglądu jaki SN wyraził w uzasadnieniu wyroku z dnia 13 października 2009 r., II PK 96/09.

Drugi argument dotyczy uzyskania prawomocności zaskarżonego orzeczenia o zwrocie pozwu. Przepis art. $130^{2} \S 2$ k.p.c. można

15 Co do zagadnienia zob. szerzej, P. Pogonowski, Zakaz 'reformationis in peius' w postepowaniu cywilnym, Warszawa 2004, s. 184 i n.

16 Zob. T. WiŚnIEwsKi, [w:] Kodeks postępowania cywilnego. Komentarz, pod red. H. Doleckiego i T. Wiśniewskiego, II, Warszawa 2010, s. 107.

17 Zob. M. ZielińsKi, Wykładnia prawa. Zasady, reguły, wskazówki, Warszawa 2002, s. 228. 
interpretować również w ten sposób, że ustawodawca przedłuża skuteczność zarządzenia do czasu uzupełnienia opłaty. Powstaje zatem pytanie, czy termin do uzupełnienia biegnie wyłącznie od daty doręczenia zarządzenia o zwrocie pisma, czy też przepis ten, w oparciu o dyrektywy funkcjonalne oraz systemowe, będzie także obowiązywał w razie wniesienia zażalenia na zarządzenie o zwrocie pozwu. W artykule uznano za właściwą drugą ewentualność. Należy pamiętać, że przepisy dotyczące wyroków, w tym także dotyczące prawomocności formalnej, stosowane są do zarządzeń przewodniczącego na podstawie podwójnego odesłania, co zakłada ostrożność w ich stosowaniu. Zgodnie z art. 362 k.p.c. przepisy rozdziału regulującego postanowienia stosuje się odpowiednio do zarządzeń przewodniczącego. Z kolei na podstawie art. 361 k.p.c. do postanowień stosuje się odpowiednio przepisy o wyrokach, jeżeli kodeks nie stanowi inaczej. W opracowaniu uznano, że przepis art. $130^{2} \S 2$ k.p.c. stanowi wyjątek zarówno od zasady prawomocności orzeczeń drugiej instancji, jak i od zasady prawomocności postanowień sądu wydanych w pierwszej instancji (art. 360 k.p.c.). Na podstawie argumentów opartych o wykładnię funkcjonalną jak i systemową uznano, że art. $130^{2} \S 2$ k.p.c. ma również zastosowanie w sytuacji, kiedy to zostało wniesione zażalenie na zarządzenie o zwrocie pozwu z powodu braku fiskalnego. W powyższym przepisie ustawodawca uzależnił skuteczność orzeczenia o zwrocie od uzupełnienia braku fiskalnego w ustawowym, tygodniowym, terminie.

Trzeci, ostatni argument, dotyczy powołania się na brzmienie art. 112 ust. 3 ustawy z dnia 28 lipca 2005 r. o kosztach sądowych w sprawach cywilnych. Można przyjąć, że gdyby intencją ustawodawcy było objęcie szerszym zakresem zastosowania art. $130^{2} \S 2$ k.p.c., również do biegu terminu do opłacenia pisma, gdy strona wniosła zażalenie, następnie oddalone, znalazłoby to odzwierciedlenie w hipotezie tego przepisu. Z drugiej strony, art. 112 ust. 3 u.k.s.c. otrzymał obecne brzmienie ustawą z dnia 17 grudnia 2009 r. o zmianie ustawy - Kodeks postępowania cywilnego oraz niektórych innych ustaw (Dz. U. z 2010 r. Nr 7, poz. 45), obowiązującą od dnia 19 kwietnia 2010 r. Wcześniejsze orzecznictwo SN, przytoczone w niniejszym artykule, opowiadało się przeciwko rygorystycznej wykładni art. $130^{2} \S 3$ k.p.c. uznając, że za- 
ostrzenie wymogów formalnych i fiskalnych w przypadku wniesienia pisma przez wykwalifikowanego prawnika, nie może być wyinterpretowane $\mathrm{z}$ obowiązujących przepisów. Ponadto, przedstawione zagadnienie dotyczy także wykładni przepisów regulujących zażalenie. Trudno zaakceptować tak daleko posuniętą kazuistykę ustawodawcy, który określałby skutki oddalenia zażalenia na poszczególne postanowienia (zarządzenia).

\section{WNIOSKI}

W przypadku wniesienia zażalenia na zarządzenie o zwrocie pozwu $\mathrm{z}$ powodu braku fiskalnego odpowiednie zastosowanie ma art. $130^{2}$ $\S 2$ k.p.c.

Ustawodawca nie uregulował sytuacji, kiedy to strona reprezentowana przez profesjonalnego pełnomocnika zamiast uiścić brakującą opłatę wnosi zażalenie na zarządzenie o zwrocie pozwu. Należy uznać, że po oddaleniu zażalenia zastosowanie znajdzie art. $130^{2} \S 2$ k.p.c., który umożliwi w ustawowym terminie uzupełnienie braku fiskalnego. W artykule zajęto stanowisko, zgodnie z którym początek biegu siedmiodniowego terminu do uzupełnienia braku fiskalnego, o którym mowa w art. $130^{2} \S 2$ k.p.c., w razie wniesienia zażalenia na zarządzenie o zwrocie pozwu, rozpoczyna się od doręczenia postanowienia sądu oddalającego zażalenie.

Profesjonalny pełnomocnik wnoszący zażalenie nie może jednocześnie uzupełnić braku fiskalnego, gdyż wnosząc zażalenie strona nie posiadałaby interesu prawnego, skoro brak fiskalny został uzupełniony. Strona wnosząca zażalenie nie może być stawiana w gorszej sytuacji procesowej niż strona nie korzystająca z tego środka zaskarżenia. Przeciwny pogląd należałoby uznać za sprzeczny z zagwarantowanymi przez Konstytucję RP, zasadami prawa do sądu oraz instancyjności postępowania, jak również za sprzeczny z zakazem reformationis in peius.

Brak jest podstawy prawnej do wyłączenia możliwości uzupełniania braku fiskalnego w przypadku wniesienia zażalenia przez profesjonalnego pełnomocnika. Wniesienie zażalenia nie może prowadzić 
do wyłączenia postępowania naprawczego, o którym mowa w art. $130^{2} \S 2$ k.p.c. Zażalenie może zostać wniesione jedynie od zarządzenia, które jest nieskuteczne, a zatem art. $130^{2} \S 2$ k.p.c. stanowi lex specialis wobec art. 360 k.p.c. w zW. z art. 362 k.p.c. Ustawodawca uzależnił skuteczność zarządzenia od nieuzupełnienia braku fiskalnego we wskazanym terminie ustawowym. Przepis art. $130^{2} \S 2$ k.p.c. dotyczy tak uzupełnienia braku fiskalnego $\mathrm{w}$ razie niewniesienia jak i wniesienia zażalenia.

Wykładnia art. $130^{2} \S 2$ k.p.c. powinna wykluczyć możliwość toczenia się postępowania pomimo nienależytego opłacenia pisma (art. $126^{2} \S 1$ k.p.c.). Sytuacja taka mogłaby wystąpić wówczas, jeżeli pełnomocnik uzupełniłby brak fiskalny, stosownie do art. $130^{2} \S 2$ k.p.c., a jednocześnie wniósłby zażalenie, które uwzględniłby sąd drugiej instancji. Należy podkreślić, że przepisy k.p.c. regulujące wniesienie zażalenia na zarządzenie o zwrocie pozwu, jeżeli strona nie jest reprezentowana przez profesjonalnego pełnomocnika, wykluczają taką ewentualność.

De lege ferenda należy postulować dodanie do art. $130^{2} \S 2$ k.p.c. przepisu, który umożliwiałby uzupełnienie przez profesjonalnego pełnomocnika braku fiskalnego pisma w terminie siedmiodniowym od daty doręczenia postanowienia oddalającego zażalenie na zarządzenie o zwrocie pozwu z powodu braku fiskalnego. Wykładnia przepisów k.p.c. regulujących skutki nieuzupełnienia braków fiskalnych pozwu nie powinna bowiem budzić wątpliwości.

The Term in Which a Professional Proxy Must Make the Required Payment for an Appeal against a Ruling Dismissing Proceedings

\section{Summary}

The aim of this paper is to answer the question whether the provisions of Art. $1302 \$ 2$ of the Polish Civil Proceedings Code (k.p.c.) are applicable in the event of an appeal against a ruling to dismiss a case on grounds of non-payment of the court fee. Doubts have been 
raised on the admissibility of payment by a professional attorney within a term of seven days of the service of a court's decision to dismiss a case. Under Art. $1302 \$ 2$ k.p.c. the legislator has allowed for payment of the court fee due within a term of one week from the day on which notice is served on the court's decision to dismiss the case. The position of the author of this paper is that the term of seven days provided for the remittance of the court fee due in the event of an appeal, as defined in Art. $1302 \$ 2$ k.p.c., starts on the day notice is served on the court's decision to dismiss a case. Any other position on the matter would be in breach of the legal principles at the root of an individual's right of access to the law and his right to appeal, as guaranteed by the Constitution of the Republic of Poland, as well as in breach of the prohibition of reformationis in peius. The lodging of an appeal cannot lead to the dismissal of the civil recovery proceedings defined in Art. $1302 \$ 2$ k.p.c. 